$11-1-2012$

\title{
Ferrieri's Index of Openness Applied to Remittances to Developing Countries
}

Gaetano Ferrieri

Studi Interdisciplinari, Italy, ferrieri@aisigf.org

Follow this and additional works at: http://digitalcommons.wayne.edu/jmasm

Part of the Applied Statistics Commons, Social and Behavioral Sciences Commons, and the Statistical Theory Commons

\section{Recommended Citation}

Ferrieri, Gaetano (2012) "Ferrieri's Index of Openness Applied to Remittances to Developing Countries," Journal of Modern Applied Statistical Methods: Vol. 11 : Iss. 2 , Article 21.

DOI: $10.22237 /$ jmasm/1351743600

Available at: http://digitalcommons.wayne.edu/jmasm/vol11/iss2/21

This Regular Article is brought to you for free and open access by the Open Access Journals at DigitalCommons@WayneState. It has been accepted for inclusion in Journal of Modern Applied Statistical Methods by an authorized editor of DigitalCommons@WayneState. 


\title{
Ferrieri's Index of Openness Applied to Remittances to Developing Countries
}

\author{
Gaetano Ferrieri \\ Studi Interdisciplinari, \\ AISI, BA, Italy
}

A new methodology to measure international openness and globalization is described. This allows capacity to be effectively combined with size in a number of socio-economic areas, such as trade, migration and foreign investment. The method is applied to remittances to developing countries.

Key words: Openness index, statistical methods, remittances, globalization.

Introduction

A new method to measure international openness, hereafter termed the Ferrieri's Index of Openness (FIO), consists of a synthetic indicator to measure the capacity of countries for various socio-economic phenomena adjusted by weight and including the influence of other key related aggregates, such as population or gross domestic product (Ferrieri, 2010; 2006). The FIO has been applied to a number of transferable socio-economic phenomena, for example, trade, foreign direct investment and migration. This article applies the method to analyzing remittances to developing countries and demonstrates it using sample calculations and detailed technical observations.

\section{Overview}

Compared with previous work with the FIO (Ferrieri 2010), the innovative methodology is applied to another macroeconomic context by analyzing remittances to developing countries. It is further shown its effectiveness in providing a more comprehensive approach for measuring distinctly relative and absolute dimensions.

Gaetano Ferrieri $(\mathrm{PhD})$ is the founding director of AISI, an independent think-tank of interdisciplinary studies devoted to International Development (Italy). His research interests include: measuring methods (e.g., synthetic indicators), global integration, international relations and labor markets. Email him at: ferrieri@aisigf.org (1); gaetanoferrieri@tiscali.it (2).
Data regarding inflow remittances are employed to developing countries and sample calculations and detailed technical observations are suitably provided. Some advice regarding the elaboration of basic data is also provided and applied, for example, use of three-year averages in order to reduce yearly fluctuations in the main aggregate. Data collection, preparation and normalization for capacity effect and adjusting for size effect are illustrated. In addition, the choice of coefficient of variation ( $\mathrm{CV}$ or $k$ factor) of the denominator of the basic indicator is explained along with the index range (0-1), including the specific role of the coefficient of variation $(k)$. Illustrations (Tables $3 a$ and $3 b$ ) show the top performers in terms of difference in value between synthetic index and normalized indicator, and in terms of rank. The benefits and limits when reducing the maximum reachable size from $100 \%$ of the total of the countries (standard or basic scenario) to a lower proportion are described. Finally, further technical observations on the index formulation and applications are provided.

\section{Methodology}

Remittances are defined as the sum of workers' remittances, compensation of employees and migrant transfers (World Bank, 2010). Together with foreign direct investment and official development aid, they represent a key financial source for developing countries. International remittance data are typically expressed in US dollars and are managed and published by the World Bank (World Bank, 2011). Like other macroeconomic indicators, statistical measures 


\section{GAETANO FERRIERI}

related to this aggregate are provided in both absolute and relative terms, often as a percentage of the gross domestic product (GDP) in receiving countries. Both absolute and relative perspectives provide useful, but distinct, snapshots of the phenomenon. Size represents a key factor in influencing the results provided by the sole relative approach - that is, remittances as proportion of GDP in receiving countries impeding big economies (e.g., China, India) to match the same performance in terms of capacity of smaller ones (e.g., Tajikistan, Lesotho). Thus, there is a need to compare countries by following a more comprehensive approach that adequately considers and combines capacity and size in order to reduce the gap between big and small economies, to recognize the importance of size (and related factors) and to preserve the role of capacity. Based on its formulation and ability to consider a wide range of applications to transferable phenomena, Ferrieri's Index of Openness (FIO) appears to offer a suitable and effective methodological tool for this purpose.

The FIO is a mathematical function that combines the capacity of countries for a given transferable phenomenon with their share in the same, taking into consideration the influence of other key related aggregates, for example, gross domestic product (GDP). Similar to other transferable phenomena, the FIO can be applied to both inflow and outflow remittances. This article focuses on remittance inflows because this issue seems to be more consistent with the macroeconomic profile and situations of developing countries. Analogous to other phenomena, such as trade and migration, the FIO calculation methodology applied to remittances is articulated in two phases.

\section{Phase 1}

Data related to aggregates to be analyzed must be collected; in this case, inflow remittances (REM) to developing countries and their gross domestic product (GDP). Remittance data used in this study are from the World Bank and GDP data are from the International Monetary Fund (IMF). Data are expressed in US dollars at market exchange rates. Only countries with available and comparable data (both REM and GDP) in the given time horizon are considered. These data were used to elaborate the basic indicator REM-to-GDP ratio. Because remittances, like other macroeconomic aggregates, can fluctuate from year to year, three-year averages were calculated for preparing the basic indicator REM-to-GDP ratio. The REM-to-GDP ratio was then elaborated for all countries to be monitored and analyzed. Although the first two decimals can be retained for illustration purposes (tables, graphs, etc.), all figures are considered in electronic calculations in order to better define their precise ranking.

The indicator values were normalized on a scale to one, in which unity corresponds to the highest value across all countries analyzed. In this work, the benchmark is the maximum value at the current data point (three-year average: 2008-10). In order to determine time comparisons without needing to index recalculations, it is suitable to fix the highest value observed over time or a given time horizon as the benchmark (Ferrieri 2010; 2006).

Phase 2

Phase 2 consists in adjusting the country indicator values normalized for weight of the country in the total aggregate, which is their total remittances, while at the same time taking into consideration the dispersion of the denominator of the basic indicator, the GDP. This second step starts by calculating the weight or share (not in percentage terms) of each country in the total aggregate (remittances). Note that, although only up to three decimals are shown in illustrations, all decimals are (and should be) considered in electronic calculations. These weights are then subtracted from one, when unity corresponds to the theoretical maximum share (total of countries in the standard approach). These calculated differences are then raised to the coefficient of variation $(\mathrm{CV}=$ standard deviation divided by mean $)$ of the aggregate defined by the denominator of the basic indicator: in this case GDP. This factor measures the relative dispersion of the second aggregate expressing the basic indicator.

As noted, the denominator is very important in determining the basic indicator value. Until 2006, this second aggregate was considered the first exponent in the FIO formula because its statistical influence was considered 


\section{FERRIERI'S INDEX OF OPENNESS FOR DEVELOPING COUNTRY REMITTANCES}

to be similar to that of the main aggregate (numerator). Accordingly, the weight of the countries in total GDP was calculated and this share subtracted from one; this was then multiplied by the difference from one related to the key aggregate (numerator) and the result was considered the exponent of the power function in which the base was the normalized indicator value (Ferrieri, 2006).

To better identify the role played by the main aggregate (in this case, remittances), the exponent of the FIO formula was redefined by expressing the statistical importance of the denominator (the second aggregate), GDP for example, in terms of dispersion. This factor has the following properties:

1. It continues to express the importance of the aggregate at the denominator in terms of dispersion (relative variability);

2. It is constant for all countries in order to better appreciate the changes in the main aggregate; and

3. It contributes to coherent determination of the impact of size.

The coefficient of variation $(\mathrm{CV})$ is the best empirical indicator to comply with all properties and needs; a higher CV indicates a higher (relative) variability of a given related phenomenon at the denominator (in this case, GDP). Being a constant factor for all countries to be compared, a higher $\mathrm{CV}$ mainly benefits those countries with a greater size in the phenomenon concerned; in other words, it amplifies the size effect for all countries, but particularly for those having a higher weight in the phenomenon analyzed.

The formula for Ferrieri's Index of Openness (FIO) is:

$$
\text { Index }=\left(\frac{\mathrm{V}_{\mathrm{i}}}{\mathrm{V}_{\mathrm{MAX}}}\right)^{(1-\Pi)^{\mathrm{k}}}
$$

where, considering the specific phenomenon analyzed (remittances), $\mathbf{V}_{\mathbf{i}}$ is the value of the basic indicator (in this study: remittances-to-
GDP ratio) for each country in the given time; $\mathbf{V}_{\text {MAX }}$ is the maximum value of the basic indicator across the countries; $\boldsymbol{\Pi}$ is the share of each country in the world aggregate considered (in this study: remittance inflows) in the given time, not expressed in percentage terms; $\boldsymbol{\kappa}$ is the coefficient of variation of the denominator (in this study: GDP) calculated over the countries analyzed in the given time, not expressed in percentage terms.

The two different effects determining the FIO value are defined respectively as capacity effect and size effect. These are calculated as:

and

$$
\text { Capacity Effect }=\boldsymbol{V} \boldsymbol{i} / \boldsymbol{V}_{\boldsymbol{M A X}}
$$

$$
\text { Size Effect }=(1-\pi)^{\boldsymbol{n}}
$$

where exponent $\boldsymbol{\kappa}=$ constant

The index value is determined by the capacity effect (base of the power), when the size effect (exponent of the power) implies a growth in the index value for all countries, as much higher as their share in the phenomenon concerned (Ferrieri, 2010; 2006). The maximum index value is one and a country can realize this score in two ways:

1. By matching the best capacity (highest indicator value), or mathematically: $\mathbf{V i}=$ $\mathbf{V}_{\mathbf{M A X}}$, therefore $\mathbf{V i} / \mathbf{V}_{\mathbf{M A X}}=1$ and FIO $=1$; or

2. By monopolizing the whole phenomenon or reaching the theoretical best size. It should be noted that, although this latter hypothesis is both unlikely and unrealistic, it should be retained in mathematical terms. Under this (extreme) hypothesis, mathematically: (1 (I) ${ }^{\boldsymbol{\kappa}}=(1-1)^{\mathbf{K}}=0$, therefore FIO $=1$.

As observed, the size effect is also determined by the factor $\mathbf{k}$. Because this exponent is equal for all countries, the most benefited countries are those with a larger size (II). As intuitively understandable, a higher $\mathbf{k}$ increases the size effect, particularly for larger size countries. The best performer in terms of capacity is not influenced by any change in the $\mathbf{k}$ 


\section{GAETANO FERRIERI}

factor for the same reasons why the power function (as mathematically formulated) cannot improve or worsen a situation given by the best capacity (unity).

Two extreme cases are possible in this regard. If $\boldsymbol{\kappa}$ is equal to one (GDP standard deviation $=$ GDP mean), the index value for all countries is determined by their capacity effect and a size effect based only on their share in the phenomenon concerned. If (paradoxically) $\boldsymbol{\kappa}$ is equal to zero (GDP standard deviation $=0$ ), meaning GDP is the same for all countries (there is no variability), then the index value is only given by the capacity effect and this seems to be consistent with openness (Ferrieri, 2010). In such extreme cases, the difference between countries is given only by their basic components.

\section{Results}

The FIO was calculated over 118 developing countries with available data in both relevant aggregates: remittances and GDP. Three-year averages were calculated in order to adjust for yearly fluctuations; however, 2011 data were not considered because they were still estimations. Remittances were reported to GDP in order to build the basic indicator resulting in a remittances-to-GDP ratio for the three year average (2008-10). The countries' values for this indicator were reported to the highest value across the same countries compared (in this study: Tajikistan: $41.56 \%$ ) in order to have normalized values referring to one; this normalized indicator represents the capacity for the given phenomenon in a comparative approach. This indicator of capacity (base) was then raised to the size effect, which was calculated as the distance from one of each country's share in total remittances raised to the GDP coefficient of variation. Table 1 provides sample calculations referring to China, India and Tajikistan. Results for all countries are shown in Table 2. The FIO index values applied to remittances is conventionally defined as IOREM.

As shown in the tables, the highest indicator (REM-to-GDP ratio) value across countries compared is that of Tajikistan $(41.56 \%)$, thus the indicator value normalized to Tajikistan corresponds to the benchmark (unity).
India and China are respectively the first and second by share in total remittances, by representing respectively $16.1 \%$ and $15.8 \%$ of the total remittances among the 118 countries analyzed; without considering the size effect they would rank $58^{\text {th }}$ and $86^{\text {th }}$ out of the 118 developing countries. By taking into account the size effect, their IOREM values rise to 0.277 for India and 0.133 for China. The growth, in terms of index value, for India is $210.91 \%$ and for China is $464.19 \%$; the size effect allows India to gain 38 positions in ranking (from $58^{\text {th }}$ to $20^{\text {th }}$ ) and China 43 places (from $86^{\text {th }}$ to $43^{\text {rd }}$ ). Understandably, value and rank remain unchanged for Tajikistan, which is the best performer.

It is important to emphasize that the size effect causes index values to increase for all countries - most notably for those with higher size in the related phenomenon (i.e., remittances). The last two columns in Table 2 show rank by indicator value normalized (IVN) and IOREM (index value combining capacity with size), out of the 118 countries analyzed: 20 of them (about one sixth) improve in rank, 63 (more than half) decline in rank and 35 (less than one third) remain unchanged in their position.

The key factor determining the performances of countries is their capacity, particularly when their size is similar or not significantly different. For example, Haiti and Lithuania have a similar size in total remittances inflow, but the indicator value of Haiti is six times higher than that of Lithuania. Due to the size effect (Table 2, third column), both countries (like all others) gain in terms of value, but the higher capacity of Haiti compared to Lithuania allows Haiti to lose just one position passing from IVN to IOREM, while Lithuania loses three places. Conversely, size fosters changes in ranking between countries when their capacity is somewhat similar. For example, Lebanon has a slightly lower indicator value compared to Haiti $(21.39 \%$ versus $21.57 \%$ ), but due to the size effect, Lebanon gains one position compared to Haiti in the IOREM ranking. A similar situation is observed for Albania and Bangladesh: the indicator value (and so the indicator value normalized) of Albania is slightly higher than that of 


\section{FERRIERI'S INDEX OF OPENNESS FOR DEVELOPING COUNTRY REMITTANCES}

Bangladesh: $10.71 \%$ compared to $10.64 \%$ (or 0.258 compared to 0.256 in terms of normalized indicators). Due to the size effect, Albania loses two positions and Bangladesh gains three places in ranking (in terms of value, the IOREM of Albania is 0.263 and that of Bangladesh is 0.297).

Table 3 a shows the top 20 gainers in terms of difference in value between IOREM and IVN. Apart from China, India and Mexico, which improve exceptionally in both value and rank, other countries show high performances in terms of value but not necessarily in terms of rank. For example, Russia's index improves by $33.47 \%$ but its rank improves by just one position. By contrast, Egypt improves by $22.02 \%$ in terms of index value (less than Russia) but gains five places in rank. This is mainly due (taking also into account the different sizes of the countries) to the different capacity: the indicator value of Russia is much lower than that of Egypt (see Table 2). In another example, Ukraine with a growth of $15.70 \%$ - less than half compared to that of Russia - also gains one position. The size effect for these two countries is not dissimilar; the real difference is due to their very different capacities.

Table $3 \mathrm{~b}$ shows the top 20 gainers in terms of rank. The first three places between the two classifications (Table $3 \mathrm{a}$ and $3 \mathrm{~b}$ ) are the same, however, for newcomers like Lebanon, Azerbaijan, Jordan, Kazakhstan and the Kyrgyz Republic a slower increase in terms of value is sufficient to cause a gain in ranking comparable to that of other better performing countries in terms of value.

Table 1: Ferrieri's Index of Openness Applied to Remittances (IOREM) to Developing Countries* Sample Calculations: China, India and Tajikistan (2008-10)

\begin{tabular}{|c|c|c|c|}
\hline Variables & China & India & Tajikistan \\
\hline Remittances-to-GDP ratio (Vi) & $0.98 \%$ & $3.70 \%$ & $41.56 \%$ \\
\hline (A) Capacity Effect: $(\mathrm{IVN}=\mathrm{Vi} / \mathrm{VMAX})^{* *}$ & 0.024 & 0.089 & 1.000 \\
\hline IVN (or Vi) rank & 86 & 58 & 1 \\
\hline Share in total remittances $(\Pi)^{* * *}$ & 0.158 & 0.161 & 0.007 \\
\hline Constant $=$ coefficient of variation of GDP $(\kappa) * * * *$ & 3.59 & 3.59 & 3.59 \\
\hline (B) Size Effect: $(1-\Pi)^{\kappa}$ & 0.539 & 0.531 & 0.975 \\
\hline Index of Openness to Remittances $($ IOREM $)=(A)^{(B)}$ & 0.133 & 0.277 & 1.000 \\
\hline IOREM rank & 43 & 20 & 1 \\
\hline Difference between IOREM and IVN value & $464.19 \%$ & $210.91 \%$ & - \\
\hline Difference between IOREM and IVN rank & 43 & 38 & - \\
\hline
\end{tabular}

*REM: Remittances (US dollars at market exchange rates). GDP: (Nominal) Gross Domestic Product (US dollars at market exchange rates). Values refer to three-year averages 2008-10. Although index values are expressed up to three decimal points their ranks reflect all significant figures. Source: World Bank (2011) and IMF (2011). ** $\mathrm{V}_{\mathrm{MAX}}$ is the maximum value of $\mathrm{Vi}$ across the 118 countries analysed in the given time and corresponding to $41.56 \%$ (Tajikistan); ***The share is calculated on the total of 118 developing countries with available data; ****The coefficient of variation of GDP ( $\kappa)$ is calculated over the 118 world economies analysed. 
Table 2: Index of Openness to Remittances (IOREM): Developing Countries (2008-10)*

\begin{tabular}{|c|c|c|c|c|c|c|c|}
\hline \multirow{2}{*}{ Country } & \multirow{2}{*}{$\begin{array}{c}\text { REM/GDP\% } \\
\text { Vi }\end{array}$} & \multirow{2}{*}{$\begin{array}{c}\text { Share in total } \\
\text { REM }\end{array}$} & \multirow{2}{*}{$\begin{array}{c}\text { Size } \\
\text { Effect }\end{array}$} & \multicolumn{2}{|c|}{ Value } & \multicolumn{2}{|c|}{ Rank } \\
\hline & & & & IVN & IOREM & IVN & IOREM \\
\hline Albania & 10.71 & 0.004 & 0.985 & 0.258 & 0.263 & 21 & 23 \\
\hline Algeria & 1.35 & 0.007 & 0.976 & 0.032 & 0.035 & 79 & 80 \\
\hline Antigua and Barbuda & 1.93 & 0.000 & 1.000 & 0.046 & 0.046 & 71 & 74 \\
\hline Argentina & 0.19 & 0.002 & 0.993 & 0.005 & 0.005 & 106 & 106 \\
\hline Armenia & 9.53 & 0.003 & 0.989 & 0.229 & 0.233 & 24 & 25 \\
\hline Azerbaijan & 2.96 & 0.004 & 0.984 & 0.071 & 0.074 & 65 & 64 \\
\hline Bangladesh & 10.64 & 0.032 & 0.890 & 0.256 & 0.297 & 22 & 19 \\
\hline Belarus & 0.71 & 0.001 & 0.996 & 0.017 & 0.018 & 92 & 92 \\
\hline Belize & 5.79 & 0.000 & 0.999 & 0.139 & 0.140 & 38 & 41 \\
\hline Benin & 3.78 & 0.001 & 0.997 & 0.091 & 0.092 & 55 & 61 \\
\hline Bhutan & 0.33 & 0.000 & 1.000 & 0.008 & 0.008 & 100 & 100 \\
\hline Bolivia & 6.13 & 0.003 & 0.988 & 0.147 & 0.151 & 36 & 38 \\
\hline Bosnia \& Herzegovina & 13.00 & 0.007 & 0.975 & 0.313 & 0.322 & 16 & 17 \\
\hline Botswana & 0.75 & 0.000 & 0.999 & 0.018 & 0.018 & 91 & 91 \\
\hline Brazil & 0.25 & 0.014 & 0.951 & 0.006 & 0.008 & 105 & 103 \\
\hline Bulgaria & 3.31 & 0.005 & 0.982 & 0.080 & 0.083 & 61 & 63 \\
\hline Burkina Faso & 1.15 & 0.000 & 0.999 & 0.028 & 0.028 & 83 & 84 \\
\hline Burundi & 1.51 & 0.000 & 1.000 & 0.036 & 0.036 & 77 & 79 \\
\hline Cambodia & 3.06 & 0.001 & 0.996 & 0.074 & 0.074 & 63 & 65 \\
\hline Cameroon & 0.81 & 0.001 & 0.998 & 0.020 & 0.020 & 90 & 90 \\
\hline Cape Verde & 8.93 & 0.000 & 0.998 & 0.215 & 0.215 & 25 & 26 \\
\hline Chile & 0.00 & 0.000 & 1.000 & 0.000 & 0.000 & 118 & 118 \\
\hline China & 0.98 & 0.158 & 0.539 & 0.024 & 0.133 & 86 & 43 \\
\hline Colombia & 1.73 & 0.014 & 0.951 & 0.042 & 0.049 & 74 & 72 \\
\hline Congo, Rep. & 0.13 & 0.000 & 1.000 & 0.003 & 0.003 & 112 & 112 \\
\hline Costa Rica & 1.76 & 0.002 & 0.994 & 0.042 & 0.043 & 73 & 75 \\
\hline Côte d'Ivoire & 0.82 & 0.001 & 0.998 & 0.020 & 0.020 & 88 & 88 \\
\hline Djibouti & 3.02 & 0.000 & 1.000 & 0.073 & 0.073 & 64 & 67 \\
\hline Dominica & 5.48 & 0.000 & 1.000 & 0.132 & 0.132 & 40 & 44 \\
\hline Dominican Republic & 7.30 & 0.011 & 0.961 & 0.176 & 0.188 & 30 & 32 \\
\hline Ecuador & 4.81 & 0.008 & 0.970 & 0.116 & 0.123 & 46 & 46 \\
\hline Egypt, Arab Rep. & 4.14 & 0.025 & 0.914 & 0.100 & 0.122 & 52 & 47 \\
\hline El Salvador & 16.76 & 0.011 & 0.960 & 0.403 & 0.418 & 12 & 12 \\
\hline Ethiopia & 0.99 & 0.001 & 0.997 & 0.024 & 0.024 & 85 & 86 \\
\hline Fiji & 4.82 & 0.000 & 0.998 & 0.116 & 0.117 & 45 & 49 \\
\hline
\end{tabular}

*Notes: REM: Remittances (US dollars at market exchange rates). GDP: (Nominal) Gross Domestic Product (US dollars at market exchange rates). Values refer to three-year averages 2008-10. IVN: Indicator value normalized: $\mathrm{Vi} / \mathrm{V}_{\mathrm{MAX}}=41.56$. Size Effect: calculated by raising the difference from one values in the second column (share in total) to the $k$ value $=3.594$ (coefficient of variation of GDP). Although index values are expressed up to three decimal points, ranks reflect all significant figures. Source: World Bank (2011) and IMF (2011). 
FERRIERI'S INDEX OF OPENNESS FOR DEVELOPING COUNTRY REMITTANCES

Table 2 (continued): Index of Openness to Remittances (IOREM): Developing Countries (2008-10)*

\begin{tabular}{|c|c|c|c|c|c|c|c|}
\hline \multirow{2}{*}{ Country } & \multirow{2}{*}{$\begin{array}{c}\text { REM/GDP\% } \\
\mathrm{Vi}\end{array}$} & \multirow{2}{*}{$\begin{array}{c}\text { Share in total } \\
\text { REM }\end{array}$} & \multirow{2}{*}{$\begin{array}{c}\text { Size } \\
\text { Effect }\end{array}$} & \multicolumn{2}{|c|}{ Value } & \multicolumn{2}{|c|}{ Rank } \\
\hline & & & & IVN & IOREM & IVN & IOREM \\
\hline Gambia, The & 8.46 & 0.000 & 0.999 & 0.204 & 0.204 & 26 & 27 \\
\hline Georgia & 6.38 & 0.002 & 0.992 & 0.154 & 0.156 & 35 & 35 \\
\hline Ghana & 0.43 & 0.000 & 0.999 & 0.010 & 0.011 & 96 & 97 \\
\hline Grenada & 6.86 & 0.000 & 0.999 & 0.165 & 0.165 & 33 & 34 \\
\hline Guatemala & 10.77 & 0.013 & 0.953 & 0.259 & 0.276 & 19 & 21 \\
\hline Guinea & 1.43 & 0.000 & 0.999 & 0.034 & 0.034 & 78 & 81 \\
\hline Guinea-Bissau & 5.84 & 0.000 & 0.999 & 0.141 & 0.141 & 37 & 40 \\
\hline Guyana & 13.96 & 0.001 & 0.997 & 0.336 & 0.337 & 15 & 16 \\
\hline Haiti & 21.57 & 0.004 & 0.984 & 0.519 & 0.524 & 8 & 9 \\
\hline Honduras & 18.54 & 0.008 & 0.970 & 0.446 & 0.457 & 10 & 10 \\
\hline India & 3.70 & 0.161 & 0.531 & 0.089 & 0.277 & 58 & 20 \\
\hline Indonesia & 1.17 & 0.022 & 0.925 & 0.028 & 0.037 & 82 & 78 \\
\hline Iran, Islamic Rep. & 0.30 & 0.004 & 0.987 & 0.007 & 0.008 & 104 & 104 \\
\hline Iraq & 0.09 & 0.000 & 0.999 & 0.002 & 0.002 & 115 & 115 \\
\hline Jamaica & 15.42 & 0.006 & 0.977 & 0.371 & 0.380 & 13 & 14 \\
\hline Jordan & 15.26 & 0.012 & 0.959 & 0.367 & 0.383 & 14 & 13 \\
\hline Kazakhstan & 0.19 & 0.001 & 0.997 & 0.004 & 0.005 & 108 & 107 \\
\hline Kenya & 5.56 & 0.005 & 0.981 & 0.134 & 0.139 & 39 & 42 \\
\hline Kosovo & 17.69 & 0.003 & 0.989 & 0.426 & 0.430 & 11 & 11 \\
\hline Kyrgyz Republic & 24.25 & 0.004 & 0.987 & 0.584 & 0.588 & 6 & 5 \\
\hline Lao PDR & 0.55 & 0.000 & 1.000 & 0.013 & 0.013 & 95 & 95 \\
\hline Lebanon & 21.39 & 0.023 & 0.918 & 0.515 & 0.543 & 9 & 8 \\
\hline Lesotho & 34.28 & 0.002 & 0.993 & 0.825 & 0.826 & 2 & 2 \\
\hline Liberia & 4.04 & 0.000 & 1.000 & 0.097 & 0.097 & 54 & 59 \\
\hline Libya & 0.02 & 0.000 & 1.000 & 0.001 & 0.001 & 117 & 117 \\
\hline Lithuania & 3.51 & 0.004 & 0.984 & 0.085 & 0.088 & 59 & 62 \\
\hline Macedonia, FYR & 4.13 & 0.001 & 0.996 & 0.099 & 0.101 & 53 & 57 \\
\hline Malaysia & 0.58 & 0.004 & 0.986 & 0.014 & 0.015 & 94 & 94 \\
\hline Maldives & 0.19 & 0.000 & 1.000 & 0.004 & 0.004 & 107 & 108 \\
\hline Mali & 4.86 & 0.001 & 0.995 & 0.117 & 0.118 & 44 & 48 \\
\hline Mauritius & 2.31 & 0.001 & 0.998 & 0.056 & 0.056 & 69 & 70 \\
\hline Mexico & 2.33 & 0.074 & 0.759 & 0.056 & 0.112 & 68 & 52 \\
\hline Moldova & 25.88 & 0.005 & 0.983 & 0.623 & 0.628 & 4 & 4 \\
\hline Mongolia & 4.27 & 0.001 & 0.997 & 0.103 & 0.103 & 50 & 56 \\
\hline Montenegro & 7.08 & 0.001 & 0.997 & 0.170 & 0.172 & 32 & 33 \\
\hline
\end{tabular}

*Notes: REM: Remittances (US dollars at market exchange rates). GDP: (Nominal) Gross Domestic Product (US dollars at market exchange rates). Values refer to three-year averages 2008-10. IVN: Indicator value normalized: $\mathrm{Vi} / \mathrm{V}_{\mathrm{MAX}}=41.56$. Size Effect: calculated by raising the difference from one values in the second column (share in total) to the $k$ value $=3.594$ (coefficient of variation of GDP). Although index values are expressed up to three decimal points, ranks reflect all significant figures. Source: World Bank (2011) and IMF (2011). 
GAETANO FERRIERI

Table 2 (continued): Index of Openness to Remittances (IOREM): Developing Countries (2008-10)*

\begin{tabular}{|c|c|c|c|c|c|c|c|}
\hline \multirow{2}{*}{ Country } & \multirow{2}{*}{$\begin{array}{c}\text { REM/GDP\% } \\
\text { Vi }\end{array}$} & \multirow{2}{*}{$\begin{array}{c}\text { Share in total } \\
\text { REM }\end{array}$} & \multirow{2}{*}{$\begin{array}{c}\text { Size } \\
\text { Effect }\end{array}$} & \multicolumn{2}{|c|}{ Value } & \multicolumn{2}{|c|}{ Rank } \\
\hline & & & & IVN & IOREM & IVN & IOREM \\
\hline Morocco & 7.23 & 0.021 & 0.928 & 0.174 & 0.197 & 31 & 31 \\
\hline Mozambique & 1.22 & 0.000 & 0.999 & 0.029 & 0.029 & 80 & 82 \\
\hline Myanmar & 0.33 & 0.000 & 0.999 & 0.008 & 0.008 & 101 & 101 \\
\hline Namibia & 0.14 & 0.000 & 1.000 & 0.003 & 0.003 & 111 & 111 \\
\hline Nepal & 22.33 & 0.010 & 0.966 & 0.537 & 0.549 & 7 & 7 \\
\hline Nicaragua & 12.59 & 0.003 & 0.991 & 0.303 & 0.306 & 17 & 18 \\
\hline Niger & 1.71 & 0.000 & 0.999 & 0.041 & 0.041 & 75 & 76 \\
\hline Nigeria & 5.12 & 0.031 & 0.892 & 0.123 & 0.154 & 41 & 37 \\
\hline Pakistan & 5.06 & 0.027 & 0.907 & 0.122 & 0.148 & 43 & 39 \\
\hline Panama & 0.82 & 0.001 & 0.998 & 0.020 & 0.020 & 89 & 89 \\
\hline Papua New Guinea & 0.16 & 0.000 & 1.000 & 0.004 & 0.004 & 109 & 110 \\
\hline Paraguay & 3.77 & 0.002 & 0.993 & 0.091 & 0.092 & 57 & 60 \\
\hline Peru & 1.81 & 0.008 & 0.972 & 0.044 & 0.048 & 72 & 73 \\
\hline Philippines & 11.05 & 0.063 & 0.792 & 0.266 & 0.350 & 18 & 15 \\
\hline Romania & 3.44 & 0.019 & 0.933 & 0.083 & 0.098 & 60 & 58 \\
\hline Russian Federation & 0.38 & 0.018 & 0.938 & 0.009 & 0.012 & 97 & 96 \\
\hline Rwanda & 1.63 & 0.000 & 0.999 & 0.039 & 0.039 & 76 & 77 \\
\hline Samoa & 26.30 & 0.000 & 0.998 & 0.633 & 0.633 & 3 & 3 \\
\hline São Tomé \&Principe & 1.14 & 0.000 & 1.000 & 0.027 & 0.027 & 84 & 85 \\
\hline Senegal & 10.73 & 0.004 & 0.984 & 0.258 & 0.264 & 20 & 22 \\
\hline Serbia & 7.94 & 0.011 & 0.963 & 0.191 & 0.203 & 27 & 28 \\
\hline Seychelles & 1.17 & 0.000 & 1.000 & 0.028 & 0.028 & 81 & 83 \\
\hline Sierra Leone & 2.31 & 0.000 & 1.000 & 0.056 & 0.056 & 70 & 71 \\
\hline Solomon Islands & 0.35 & 0.000 & 1.000 & 0.008 & 0.008 & 99 & 99 \\
\hline South Africa & 0.31 & 0.003 & 0.989 & 0.007 & 0.008 & 102 & 102 \\
\hline Sri Lanka & 7.91 & 0.011 & 0.961 & 0.190 & 0.203 & 28 & 29 \\
\hline St. Kitts \&Nevis & 6.43 & 0.000 & 1.000 & 0.155 & 0.155 & 34 & 36 \\
\hline St. Lucia & 2.72 & 0.000 & 1.000 & 0.065 & 0.066 & 67 & 69 \\
\hline St. Vincent \& Grenadines & 4.47 & 0.000 & 1.000 & 0.108 & 0.108 & 48 & 53 \\
\hline Sudan & 4.15 & 0.008 & 0.973 & 0.100 & 0.106 & 51 & 54 \\
\hline Suriname & 0.11 & 0.000 & 1.000 & 0.003 & 0.003 & 113 & 113 \\
\hline Swaziland & 3.07 & 0.000 & 0.999 & 0.074 & 0.074 & 62 & 66 \\
\hline Syrian Arab Republic & 2.77 & 0.005 & 0.983 & 0.067 & 0.070 & 66 & 68 \\
\hline Tajikistan & 41.56 & 0.007 & 0.975 & 1.000 & 1.000 & 1 & 1 \\
\hline Tanzania & 0.11 & 0.000 & 1.000 & 0.003 & 0.003 & 114 & 114 \\
\hline
\end{tabular}

*Notes: REM: Remittances (US dollars at market exchange rates). GDP: (Nominal) Gross Domestic Product (US dollars at market exchange rates). Values refer to three-year averages 2008-10. IVN: Indicator value normalized: $\mathrm{Vi} / \mathrm{V}_{\mathrm{MAX}}=41.56$. Size Effect: calculated by raising the difference from one values in the second column (share in total) to the $k$ value $=3.594$ (coefficient of variation of GDP). Although index values are expressed up to three decimal points, ranks reflect all significant figures. Source: World Bank (2011) and IMF (2011). 


\section{FERRIERI’S INDEX OF OPENNESS FOR DEVELOPING COUNTRY REMITTANCES}

Table 2 (continued): Index of Openness to Remittances (IOREM): Developing Countries (2008-10)*

\begin{tabular}{|c|c|c|c|c|c|c|c|}
\hline \multirow{2}{*}{ Country } & \multirow{2}{*}{$\begin{array}{c}\text { REM/GDP\% } \\
\text { Vi }\end{array}$} & Share in total & \multirow{2}{*}{$\begin{array}{c}\text { Size } \\
\text { REM }\end{array}$} & Effect & \multicolumn{2}{|c|}{ Value } & \multicolumn{2}{c|}{ Rank } \\
\cline { 6 - 8 } & & IVN & IOREM & IVN & IOREM \\
\hline Thailand & 0.62 & 0.006 & 0.980 & 0.015 & 0.016 & 93 & 93 \\
\hline Togo & 10.55 & 0.001 & 0.996 & 0.254 & 0.255 & 23 & 24 \\
\hline Tonga & 24.28 & 0.000 & 0.999 & 0.584 & 0.585 & 5 & 6 \\
\hline Tunisia & 4.46 & 0.006 & 0.978 & 0.107 & 0.113 & 49 & 51 \\
\hline Turkey & 0.16 & 0.003 & 0.988 & 0.004 & 0.004 & 110 & 109 \\
\hline Uganda & 5.11 & 0.003 & 0.991 & 0.123 & 0.125 & 42 & 45 \\
\hline Ukraine & 3.78 & 0.017 & 0.939 & 0.091 & 0.105 & 56 & 55 \\
\hline Uruguay & 0.30 & 0.000 & 0.999 & 0.007 & 0.007 & 103 & 105 \\
\hline Vanuatu & 0.93 & 0.000 & 1.000 & 0.022 & 0.022 & 87 & 87 \\
\hline Venezuela, RB & 0.04 & 0.000 & 0.998 & 0.001 & 0.001 & 116 & 116 \\
\hline Vietnam & 7.35 & 0.022 & 0.923 & 0.177 & 0.202 & 29 & 30 \\
\hline Yemen, Rep. & 4.57 & 0.004 & 0.986 & 0.110 & 0.114 & 47 & 50 \\
\hline Zambia & 0.35 & 0.000 & 0.999 & 0.008 & 0.008 & 98 & 98 \\
\hline
\end{tabular}

*Notes: REM: Remittances (US dollars at market exchange rates). GDP: (Nominal) Gross Domestic Product (US dollars at market exchange rates). Values refer to three-year averages 2008-10. IVN: Indicator value normalized: $\mathrm{Vi} / \mathrm{V}_{\operatorname{MAX}}=41.56$. Size Effect: calculated by raising the difference from one values in the second column (share in total) to the $k$ value $=3.594$ (coefficient of variation of GDP). Although index values are expressed up to three decimal points, ranks reflect all significant figures. Source: World Bank (2011) and IMF (2011).

For example, the Kyrgyz Republic needs to grow by only $0.71 \%$ in value to gain one rank while Russia must increase its value by $33.47 \%$ (or 47 times more than its neighbour) to obtain the same result. The difference can be explained by the much higher capacity of Kyrgyz Republic compared to that of Russia ( $24.25 \%$ compared to $0.38 \%$ : about 64 times as much).

\section{Conclusion}

Ferrieri's Index of Openness has a wide range of applications in socio-economic fields and based on its conceptual and mathematical properties - it appears to be a valid statistical tool to analyze remittances. As shown herein, the methodology combines the capacity of countries for a given transferable phenomenon (remittances) with their size in a suitable way by considering the role of size (including any related factor) while at the same time preserving capacity. The index can be calculated on a yearly basis as well as along other time horizons, such as three-yearly basis.
To compare countries over time, a suitable benchmark in terms of capacity must be fixed: this could be the highest indicator value across countries over the given period of time. From this time comparison perspective, it can be assumed that $k$ can be calculated for the current yearly or three-yearly value for the countries to be analyzed. If one wants to appreciate changes in capacity and size, regardless of changes in terms of dispersion in GDP, it is also possible to calculate a $k$ factor over the given period of time (preferably on the basis of appropriate methods like real and/or parity power purchasing terms), by taking into account that the limit of such an approach is to have current GDP data points calculated on nominal yearly (or three-yearly) basis, and GDP variability factor ( $k$ or $\mathrm{CV}$ ) fixed on a longer time horizon. In such a situation $k=$ 0 does not necessarily mean equal GDP for the current data points, because GDP is calculated yearly or three-yearly when $k$ is over a longer time. 
GAETANO FERRIERI

Table 3a: Index of Openness to Remittances (IOREM) Differences between IOREM and IVN Values and Ranks (2008-10), Top 20 Gainers in Terms of Value*

\begin{tabular}{|c|c|c|}
\hline \multirow{2}{*}{ Country } & \multicolumn{2}{|c|}{ IOREM compared to IVN } \\
\cline { 2 - 3 } & Difference in Value (\%) & Difference in Rank \\
\hline China & 464.19 & 43 \\
\hline India & 210.91 & 38 \\
\hline Mexico & 100.04 & 16 \\
\hline Russian Federation & 33.47 & 3 \\
\hline Philippines & 31.80 & 4 \\
\hline Indonesia & 30.90 & 2 \\
\hline Brazil & 28.80 & 4 \\
\hline Nigeria & 25.25 & 5 \\
\hline Egypt, Arab Rep. & 22.02 & 4 \\
\hline Pakistan & 21.61 & 2 \\
\hline Romania & 18.22 & 2 \\
\hline Colombia & 16.76 & 3 \\
\hline Bangladesh & 16.16 & 1 \\
\hline Ukraine & 15.70 & -1 \\
\hline Vietnam & 14.37 & - \\
\hline Morocco & 13.44 & -1 \\
\hline Peru & 9.05 & - \\
\hline Thailand & 8.73 & -1 \\
\hline Algeria & 8.44 & 1 \\
\hline Turkey & 7.20 & \\
\hline
\end{tabular}

*IVN: Indicator value normalized: $\mathrm{Vi} / \mathrm{V}_{\mathrm{MAX}}=41.56$, Source: World Bank (2011) and IMF (2011)

Ferrieri (2010) illustrated the flexibility of his method in allowing a reduction in the maximum reachable size from $100 \%$ of the total of the countries (standard or basic scenario) to a lower proportion, such as $25 \%$ of the same aggregate. A reduction in the maximum reachable size allows a better balance between capacity and size.

Further details and observations are needed in this regard. Ferrieri (2010) also showed that, in a scenario characterized by a lower reachable size, all countries improve their index value, particularly those having a higher size compared to the standard situation in which the upper limit is the total of the same countries compared. Mathematically this is because (1 $\Pi)^{\kappa}$ - when the exponent $\kappa$ is constant decreases when the share $\Pi$ increases (due to the reduction in the reference aggregate or maximum reachable share). In addition, because the base $\left(\mathrm{Vi} / \mathrm{V}_{\mathrm{MAX}}\right)$ - expressed on a scale to one - is raised to a minor distance from one, the final score (index value) is higher. The total of the countries' weights $\Sigma \Pi$ will no longer be 1 (as in the basic approach, where $\Sigma \Pi$ corresponds to the total of countries compared) but will be greater depending on the reducing factor used.

For example, by reducing the maximum reachable size to one-third, $\Sigma \Pi=3$, to onefourth is 4 , to one-fifth is 5 , etc. Also, note that the size effect is determined by the factor $\mathrm{k}$ that amplifies the effect.

In summary, a reduction in maximum reachable size allows all countries, and notably those with a high weight, to reduce considerably their distance from the best(s) performer(s). Such a reduction makes the size effect more powerful. Clearly, any change in maximum 
Table 3b: Index of Openness to Remittances (IOREM)

Differences between IOREM and IVN Values and Ranks (2008-10), Top 20 Gainers in Terms of Rank*

\begin{tabular}{|c|c|c|}
\hline \multirow{2}{*}{ Country } & \multicolumn{2}{|c|}{ IOREM compared to IVN } \\
\cline { 2 - 3 } & Difference in Rank & Difference in Value (\%) \\
\hline China & 43 & 464.19 \\
\hline India & 38 & 210.91 \\
\hline Mexico & 16 & 100.04 \\
\hline Egypt, Arab Rep. & 5 & 22.02 \\
\hline Indonesia & 4 & 30.90 \\
\hline Nigeria & 4 & 25.25 \\
\hline Pakistan & 4 & 21.61 \\
\hline Philippines & 3 & 31.80 \\
\hline Bangladesh & 3 & 16.16 \\
\hline Brazil & 2 & 28.80 \\
\hline Romania & 2 & 18.22 \\
\hline Colombia & 2 & 16.76 \\
\hline Russian Federation & 1 & 33.47 \\
\hline Ukraine & 1 & 15.70 \\
\hline Turkey & 1 & 7.20 \\
\hline Lebanon & 1 & 5.58 \\
\hline Azerbaijan & 1 & 4.32 \\
\hline Jordan & 1 & 4.20 \\
\hline Kazakhstan & 1 & 1.53 \\
\hline Kyrgyz Republic & 1 & 0.71 \\
\hline
\end{tabular}

*IVN: Indicator value normalized: Vi / V $\mathrm{MAX}=41.56$, Source: World Bank (2011) and IMF (2011)

reachable size does not compromise the situation of the best performing country, which will steadily remain in the position of highest capacity. This is consistent with the conceptual and mathematical properties of the FIO as described and illustrated.

The choice of scenarios based on a reduction in maximum reachable size depends on the extent to which importance is placed on the size effect. In principle, such a decision is at the discretion of the analyst/researcher making use of the described methodology.

\section{References}

Ferrieri, G. (2006). Method for measuring international openness. Social Indicators Research 77(2), 245-255.
Ferrieri, G. (2010). Measuring openness. Journal of Modern Applied Statistical Methods, 9(1), 172-180.

Ferrieri, G. Index of international openness. Reports obtainable from: http://www.aisigf.org.

IMF. (2011). The world economic outlook database. Washington, DC. http://www.imf.org.

World Bank. (2010). Migration and remittances factbook 2011, $2^{\text {nd }}$ Edition. Washington DC. http://www.worldbank.org.

World Bank. (2011). Remittances data inflows. Washington, DC. http://www.worldbank.org. 